\title{
Paracoccidioidomycosis: sarcoid-like form in childhood *
}

\author{
Paracoccidioidomicose: forma clínica sarcoídica na infância
}

\author{
Carolina Ribas do Nascimento ${ }^{1}$ \\ Cleverson Teixeira Soares ${ }^{3}$
}

\author{
Wladimir Fiori Bonilha Delanina ${ }^{2}$
}

\begin{abstract}
Paracoccidioidomycosis is a chronic, subacute or rarely acute mycosis, with visceral and cutaneous involvement. It is potentially fatal. Children account for about $5-10 \%$ of cases. In this study, we describe the relevance of discussing possible differential diagnoses as well as the importance of early treatment.

Keywords: Child; Granuloma; Paracoccidioidomycosis

Resumo: Paracoccidioidomicose é uma micose crônica, subaguda ou raramente aguda, com comprometimento visceral e tegumentar, sendo potencialmente fatal. As crianças representam cerca de 5 a $10 \%$ dos casos. A seguir, descreve-se a necessidade da discussão dos diagnósticos diferenciais cabíveis bem como a importância do início precoce do tratamento.

Palavras-chave: Criança; Granuloma; Paracoccidioidomicose
\end{abstract}

Twelve-year old white male student from Boa Esperança, Sao Paulo.

The patient reported appearance of lesions on the face and chest in January 2009. At another service, he had been subjected to a biopsy, which showed multinucleated cells with negative sputum smears and non-visualized nerve fibers. This is consistent with granulomatous dermatitis (July/2009). He was sent to the referral service with suspected leprosy.

On examination, we found erythematous-violaceous infiltrated plaques and papules on the face, ear lobe and anterior chest (Figuras 1, 2 and 3). We also found enlargement of right posterior and anterior cervical lymph nodes (Figure 1). The liver was palpable 4 $\mathrm{cm}$ from the right costal margin.

We discussed possible diagnoses, such as para-

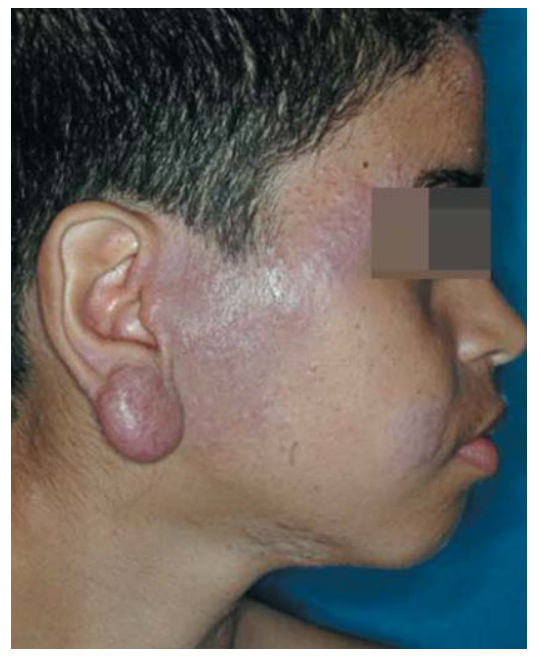

Figure 1: Right cervical region and half of the face. Erythematousviolaceous infiltrated papules and plaques on the face. Nodule on the earlobe. Enlargement of right anterior and posterior lymph nodes coccidioidomycosis, leishmaniasis, sarcoidosis, tuberculoid leprosy, and granulomatous syphilis.

The patient underwent a new biopsy, and the anatomopathological finding was consistent with paracoccidioidomycosis (Figure 4). This disease is a

Received on 03.01.2011.

Approved by the Advisory Board and accepted for publication on 07.02.2011.

* Work conducted at Instituto Lauro de Souza Lima (ILSL) - Bauru (SP), Brazil.

Conflict of interest: None

Financial funding: None

Dermatologist - MSc student in Internal Medicine - Dermatology, Federal University of Rio Grande do Sul (UFRGS) - Porto Alegre (RS), Brazil. Dermatologist - Medical Director, Division of Dermatology, Instituto Lauro de Souza Lima (ILSL) - Bauru (SP), Brazil.

MSc in pathology - Pathologist, Instituto Lauro de Souza Lima (ILSL) - Bauru (SP), Brazil. 


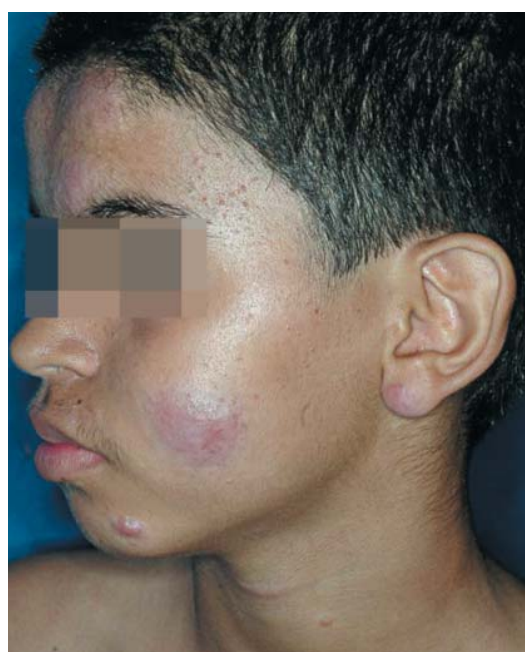

Figure 2: Left half of the face. Erythematous and violaceous infiltrated plaques and papules, corresponding to the sarcoid pattern of the disease

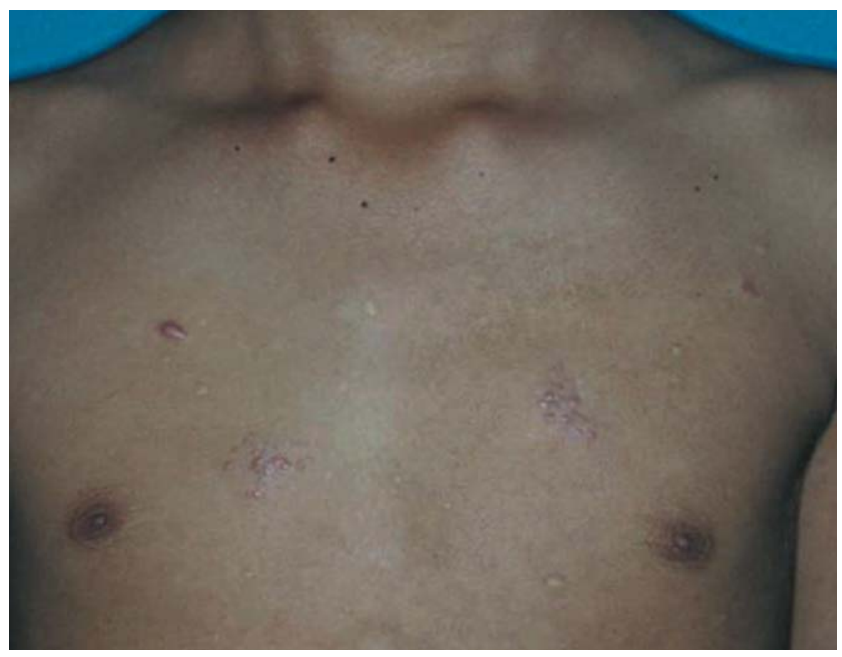

Figure 3: Anterior chest. Coalescing papules and erythematous-violaceous plaques on the anterior chest

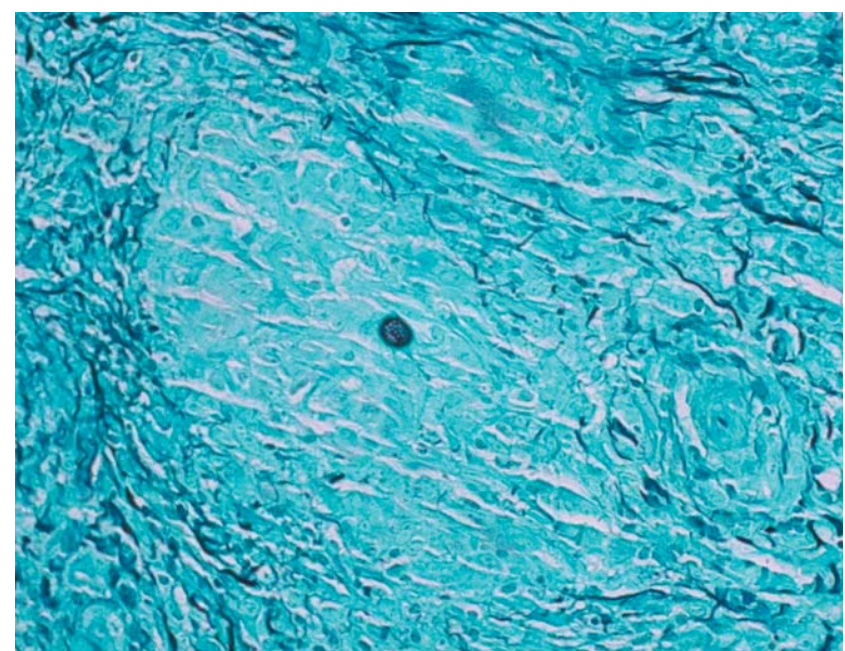

FIgURE 4: Histopathology: PAS staining demonstrating non-sporulating fungi within tuberculoid granuloma

chronic, subacute or acute mycosis that may involve the skin and viscera. ${ }^{1.5}$

It should be noted that the child was referred to the service with suspected leprosy. This hypothesis, based on initial clinical and histopathological findings, was not entirely wrong, since the tuberculoid pole of the disease spectrum may present sarcoid lesions on clinical examination and well formed granulomas on histological examination. ${ }^{3}$

To identify paracoccidioidomycosis, we used gel immunodiffusion reactive up to $1: 32$ and indirect immunofluorescence reactive up to 1:252. started.

Treatment with itraconazole $200 \mathrm{mg}$ daily was

After ten months of treatment, the patient presented no clinical lesions. There was no recurrence after over a year of follow-up and use of medication. $\square$

\section{REFERENCES}

1. Marques SA, Lastória JC, Putinatti MSMA, Camargo RMPC, Marques MEA. Paracoccidioidomycosis: infiltrated, sarcoid-like cutaneous lesions misinterpreted as tuberculoid leprosy. Rev Inst Med Trop Sao Paulo. 2008;50:47-50.

2. Shikanai MA, Filho FQT, Mendes RP, Colombo AL, Moretti ML e Grupo de Consultores do Consenso em Paracoccidioidomicose. Consenso em paracoccidioidomicose. Rev Soc Bras Med Trop. 2006;39:297-310.

3. Lacaz CS, Porto E, Martins JEC, Vaccari EMH, Melo NT. Tratado de micologia médica Lacaz. São Paulo: Savier; 2002. p. 639-729.

4. Marques SA. Paracoccidioidomicose: centenário do primeiro relato de caso. An Bras Dermatol. 2008;83:271-3.

5. Wanke B, Aidé MA. Curso de Atualização. Micoses. Paracoccidiodomicose. J Bras Pneumol. 2009;35:1245-9.

\author{
MAILING ADDRESS: \\ Carolina Ribas do Nascimento \\ Rodovia Comandante João Ribeiro de Barros, $\mathrm{Km}$ \\ 225/226. \\ 17034-971 Bauru - São Paulo, SP \\ E-mail address: dra.carolribas@gmail.com
}

How to cite this article: Nascimento CR, Delanina WFB, Soares CT. Paracoccidioidomycosis: sarcoid-like form in childhood. An Bras Dermatol. 2012;87(3):486-7. 